\title{
KRAFT LIGNIN AS AN ADDITIVE IN PINE AND EUCALYPTUS PARTICLE COMPOSITION FOR BRIQUETTE PRODUCTION
}

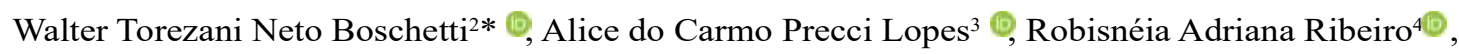 \\ Rafael Quezada Reyes ${ }^{5}$ and Angélica de Cássia Oliveira Carneiro ${ }^{6}{ }^{\circ}$
}

\footnotetext{
${ }^{1}$ Received on 29.04.2016 accepted for publication on 15.09.2017.

${ }^{2}$ Universidade Federal de Viçosa, Doutor em Ciência Florestal, Viçosa, Minas Gerais, Brasil. E-mail: <walterboschetti@gmail.com>.

${ }^{3}$ Universitat Innsbruck, Programa de Pós-Graduação em Engenharia Civil, Austria. E-mail: <alice.precci@gmail.com>.

${ }^{4}$ Universidade Federal de Viçosa, Doutora em Agroquimica, Viçosa, Minas Gerais, Brasil. E-mail. E-mail:

<adrianaribeiro_qui@yahoo.com.br>.

${ }^{5}$ Universidade Federal de Viçosa, Doutor em Ciência Florestal, Viçosa, Minas Gerais, Brasil. E-mail: <rafa1110@gmail.com>.

${ }^{6}$ Universidade Federal de Viçosa, Departamento de Engenharia Florestal, Viçosa, Minas Gerais , Brasil. E-mail:

<cassiaacarneiro@gmail.com>.

*Corresponding author.
}

\begin{abstract}
The objective of this study was to evaluate the properties of briquettes produced with different proportions of pine and eucalyptus wood, as well as to characterize the potential of kraft lignin as an additive in the composition of briquettes for energy generation. The treatments differed from one another in the pine and eucalyptus wood particle ratios $(0,25,50,75$ and 100\%), as well as for the kraft lignin content $(0,2,4,6$, $8,10$, and $12 \%)$. The biomasses were characterized by their physical and chemical properties, and briquette properties were evaluated according to apparent density, lower calorific value (LCV), energy density, and maximum burst load. The results showed an increase in the apparent density as the proportion of lignin and eucalyptus in the briquettes increased. The particle composition of the briquettes had a higher influence on the energy density increase compared to the addition of kraft lignin, being more significant in briquettes produced with higher proportions of eucalyptus. It was also observed that the addition of lignin increased the resistance to the rupture load, and that there was a specific value at which this resistance was higher (at $7 \%$ or $11 \%$ of lignin, depending on the proportion of particles). Additionally, the briquettes made with $100 \%$ pine achieved greater mechanical resistance. In general, kraft lignin presented good potential for use as a briquette additive, contributing to improved energy and mechanical properties.
\end{abstract}

Keywords: Krat lignin, Biomass energy, Briquettes.

\section{KRAFT LIGNIN AS AN ADDITIVE IN PINE AND EUCALYPTUS PARTICLE COMPOSITION FOR BRIQUETTE PRODUCTION}

RESUMO - O objetivo deste trabalho foi avaliar as propriedades de briquetes produzidos com diferentes proporções de partículas de madeira de pinus e eucalipto, bem como caracterizar o potencial de uso da lignina kraft como aditivo na composição destes briquetes para a geração de energia. Os tratamentos diferenciaramse na proporção de mistura de partículas pinus e eucalipto $(0,25,50,75$ e $100 \%)$ e na proporção de lignina kraft $(0,2,4,6,8,10 \mathrm{e} 12 \%)$. As propriedades dos briquetes foram avaliadas a partir da densidade aparente, densidade energética, resistência à carga de ruptura e do poder calorífico inferior (PCI). Os resultados indicaram um aumento de densidade aparente conforme aumentou a proporção de eucalipto e de lignina nos briquetes. A composição das partículas teve maior influência no aumento da densidade energética em relação à adição de lignina kraft, sendo mais expressiva em briquetes feitos com maior proporção de eucalipto. Foi observado ainda que a adição de lignina proporcionou maior resistência à carga de ruptura, e que existiu um valor específico em que foi mais elevado ( $7 \%$ ou $11 \%$ de lignina, dependendo da proporção de partículas). Além disso, os briquetes feitos com $100 \%$ de pinus alcançaram maior carga de ruptura. De modo geral, a lignina kraft apresentou um bom potencial para ser utilizada como aditivo em briquetes, na qual contribuiu para melhorar as suas propriedades energéticas e mecânica.

Palavras-Chave: Lignina kraft, Energia da biomassa, Briquetes

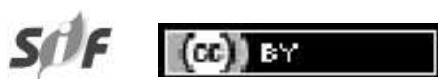

Revista Árvore 2019;43(2):e430201 http://dx.doi.org/10.1590/1806-90882019000200001 


\section{INTRODUCTION}

Kraft lignin from the cellulosic pulp industry is currently used as fuel in the chemical recovery cycle of black kraft liquor, given its potential for thermal energy generation. However, with increased productivity, the high amount of black liquor generated exceeds the burning capacity in the recovery boiler, leading to a bottleneck for the pulp industry.

An attractive alternative for the pulp industry is to extract part of the lignin from the black liquor for commercialization as an additive, which can be used in the production of briquettes, phenolic resins, dispersants and surfactants (Lora et al., 2002; Gosselink et al., 2004).

Lignin is a phenolic macromolecule that forms part of the chemical composition of the wood, acting on the adhesion of fibers. Alternative forms of lignin isolation to cooking the wood, entail significant differences in its structures and physical and chemical properties, including its original shape in the wood, which changes its potential for application (Glaser, 1981). Among its advantages, kraft lignin has adhesive characteristics and can be used as a particulate binder for the production of briquettes. However, there are still few studies related to the topic (Gouvêa et al., 2010; Valadares et al., 2011).

Briquettes are products derived from plant biomass and have high potential to supply part of the energy consumed around the world through fossil fuels, whether in the form of thermal and/or electrical energy. Still, it is a renewable, easily transportable fuel, which is easy to handle, considering that it is a compacted product, with high energy density in comparison to other biomasses (Stolarski et al., 2013).

Compaction and particle adhesion are important factors that affect the mechanical strength and durability of briquettes. These factors can be influenced by the density of the constituent particles, as already observed in briquettes made of pine and eucalyptus, in which pine particles, being less dense, compact and agglutinate better. However, they are more expensive than eucalyptus particles, which are denser and more difficult to aggregate, which can result in briquettes with low mechanical resistance and a consequent reduction of their market value (Kaliyan and Morey, 2009).
Thus, mixing different biomasses with different properties may be an alternative to reduce costs and problems related to the low mechanical resistance caused by briquettes made from a single biomass, as in the case of eucalyptus wood. Additionally, the use of additives such as lignin may contribute to increase the mechanical resistance, as well as the calorific power and energy density of the briquette.

In this context, the objective of this work was to evaluate the properties of the briquettes produced with different proportions of pine and eucalyptus wood, as well as to characterize the potential use of kraft lignin as an additive in the composition of briquettes for energy generation.

\section{MATERIAL AND METHODS}

The briquettes produced were constituted in the proportions of $0,25,50,75$ and $100 \%$ of biomass mixture: pine and eucalyptus particles. For each proportion, 2, 4, 6, 8, 10 and $12 \%$ of kraft lignin were added, excluding the control, $0 \%$ of lignin (Figure 1). In total, 35 treatments were delineated, each with 6 replications.

The lignin was isolated in the laboratory from the black kraft liquor, through the Lignoboost process (Berghel et al., 2013). Black liquor supplied from a Brazilian pulp plant was concentrated to $37 \%$ solids and acidified with carbon dioxide to $\mathrm{pH}$ 8.5. Thereafter, sulfuric acid $(20 \% \mathrm{v} / \mathrm{v})$ was added to the acidified liquor in a reactor at $\mathrm{pH} 2$, and centrifuged for 15 minutes at a rotation of 5,000 rpm. The precipitated lignin was separated by a filtration system, followed by acid washing with its respective acids and then washed with hot distilled water. The retained material was then placed in the oven with forced ventilation at a temperature of $105{ }^{\circ} \mathrm{C}$ until completely dried. The dry lignin was subsequently milled and sieved to 100 mesh granulometry to ensure better homogeneity.

\subsection{Characterization of wood and kraft lignin}

Characterization of wood and kraft lignin followed the procedures described in Table 1. The moisture content, extractives, soluble and insoluble lignin, immediate chemical analysis and higher calorific value (HCV) were analyzed for the wood. In relation to lignin, the ash content, elemental chemical analysis and HCV were analyzed.

Revista Árvore 2019;43(2):e430201 


\subsection{Production and qualification of briquettes}

The pine and eucalyptus woods were transformed into particles using a hammer mill for grinding. Subsequently, the particles were classified in a sieve with mesh 5.67 and $2.77 \mathrm{~mm}^{2}$, collecting the fraction that was retained in the last sieve.

After classification, the particles were placed in a closed circulation oven at $60 \pm 2^{\circ} \mathrm{C}$ until reaching a humidity of approximately $12 \pm 2 \%$. The moisture (dry basis) of the particles was weighed on halogen light scales.

The briquettes were produced in a Lippel brand laboratory briquette, LB-32 model, at 120 oC, with a compaction time of 5 minutes, a cooling time of 5 minutes and compaction pressure of $10.3 \times 10^{6} \mathrm{~N} . \mathrm{m}^{-2}$ (1500 PSI). The total biomass used to produce each briquette was 16 grams.

The apparent density of the briquettes was determined by weighing and subsequent immersion in mercury, obtaining the volume displaced according to the hydrostatic balance method, described by Vital (1984). The energy density was obtained by the product of the lower calorific value (LCV) by the apparent density of the briquettes. The lower calorific value (LCV) was obtained taking into account the higher calorific value (HCV) and the proportion of the hydrogen element $(\mathrm{H})$, according to equation 1 . Thus, the final LCV was calculated from the percentage proportions of eucalyptus (E), pine (P) and lignin (L) present in briquettes, according to equation 2 .

$$
\begin{aligned}
& \text { (1) } \mathrm{LCV}=\mathrm{HCV}-[600 * 9 \mathrm{H} / 100] \\
& \text { (2) } \mathrm{LCV}_{\text {Final }}=\mathrm{HCV}^{*} \mathrm{E}+\mathrm{HCV}^{*} \mathrm{P}+\mathrm{HCV}^{*} \mathrm{~L}
\end{aligned}
$$

The maximum rupture load was adapted from the ABNT NBR ISO 11093-9 (ABNT, 2009), since there is no specific standard for briquettes. The universal test machine model Losenhausen was used, with a speed of $3.5 \mathrm{~mm} . \mathrm{min}^{-1}$ compression until rupture.

\subsection{Experimental design}

The results were submitted to the Lilliefors test for normality, and the Cochran test for homogeneity of variance. The data obtained from the characterization of the particles and the kraft lignin was submitted to analysis of variance to verify the differences between the treatments. When significant differences were observed, the t-test was applied at 95\% significance.

The data obtained for each briquette qualification parameter, composed of different proportions of pine and eucalyptus particles, and treated with different percentages of lignin as an additive $(0,2,4,6,8,10$, $12 \%$ ) was statistically analyzed by means of regression analysis. The adjusted equations were compared by the $\mathrm{F}$ test, using the model identity test adopting a significance of up to $5 \%$ probability, according to the Regazzi (1993) methodology for linear models, and Regazzi and Silva (2004) for nonlinear models. The choice of model was based on the highest coefficient of determination $\left(\mathrm{R}^{2}\right)$, significant $\mathrm{F}$ test, standard error of the estimate and on the graphical distribution of the residues.

\section{RESULTS}

\subsection{Physical and chemical characteristics of wood and kraft lignin}

Table 1 shows the average values of the physical and chemical properties of the raw materials used to produce the briquettes. Note that kraft lignin has energy potential to be used as an additive in briquettes.

Table 1 - Wood and lignin characterization and their respective standards.

\begin{tabular}{|c|c|c|}
\hline & Parameter & Procedure \\
\hline \multirow[t]{5}{*}{ Wood } & $\begin{array}{l}\text { Soluble extractives } \\
\text { Insoluble lignin }\end{array}$ & $\begin{array}{c}\text { TAPPI T264 cn-97 (1997) } \\
\text { Gomide and Demuner (1986) }\end{array}$ \\
\hline & Soluble lignin & Goldschmid (1971) \\
\hline & Immediate Chemical Analysis & ABNT NBR 8112 (1983) \\
\hline & Higher Calorific Value & ASTM D-2015-66 (1982) \\
\hline & Elementary Chemical Analysis & ASTM, D1762-84 (2001) \\
\hline \multirow[t]{3}{*}{ Lignin } & Immediate Chemical Analysis & ABNT NBR 8112 (1983) \\
\hline & Higher Calorific Value & ASTM D-2015-66 (1982) \\
\hline & Elementary Chemical Analysis & ASTM, D1762-84 (2001) \\
\hline
\end{tabular}

Tabela 1 - Caracterização da madeira e da lignina e suas respectivas metodologias 


\subsection{Briquettes properties}

Figure 1 shows the effect of the proportion of eucalyptus particles on the apparent density of briquettes when different percentages of kraft lignin were added. The model identity test for the variables being studied was significant, so two equations were estimated for the apparent density of the briquettes, one as a function of the proportion of particles (Figure 1a), and the other as a function of the proportion of kraft lignin added to the briquettes (Figure 1b). The quadratic regression model was the one that best explained the effect of the apparent density of the briquettes with the addition of kraft lignin and the proportion of particles in the composition of the briquettes.

Figure 2 shows the effect of the proportion of eucalyptus particles on the lower calorific value of the briquettes, through the estimated values, when different percentages of kraft lignin were added. The model identity test for the variables being studied was also significant, and two equations were estimated for the lower calorific value of the briquettes, one as a function of the proportion of particles (Figure 2a), and the other as a function of the proportion of kraft lignin added to the briquettes (Figure $2 b$ ). The linear regression model best explained the effect of the calorific value of the briquettes with the addition of kraft lignin and the proportion of particles in the composition of the briquettes.
Figure 3 a shows the effect of the addition of lignin on the energy density of briquettes made using different biomass proportions. According to the model identity F test, the equality of curves hypothesis was rejected. Thus, five models were adjusted for energy density as a function of the proportion of added kraft lignin. The quadratic regression model was the one that best explained the effect of the addition of lignin on the energy density of the briquettes.

Figure $3 b$ shows the effect of lignin addition on the maximum burst load of briquettes made with different biomass proportions. The equation of curves hypothesis was also rejected according to the F model identity test. In this way, five models were adjusted for the maximum rupture load as a function of the proportion of added kraft lignin. The quadratic regression model was the one that best explained the effect of lignin addition on the maximum burst load of the briquettes.

\section{DISCUSSION}

\subsection{Physical and chemical characteristics of wood and kraft lignin}

Although kraft lignin presented better energetic characteristics, such as higher apparent density and higher LCV, a high ash content was observed, considering that values greater than $1 \%$ of ash in kraft lignin extracted by the Lignoboost process are considered high (Tomani, 2010).

Table 2 - Mean values of chemical and physical properties of pines wood, eucalyptus wood and kraft lignin.

Tabela 2 - Valores médios das propriedades químicas e fisicas da madeira de pinus, eucalipto e da lignina kraft.

\begin{tabular}{|c|c|c|c|}
\hline Characteristics & Pine & Eucalyptus & Lignin \\
\hline Bulk Density of Forest Biomass $\left(\mathrm{kg} \cdot \mathrm{m}^{-3}\right)$ & 93 (c) & $137(b)$ & 427 (a) \\
\hline High Calorific Value (kcal. $\left.\mathrm{kg}^{-1}\right)$ & $4810(b)$ & $4737(\mathrm{c})$ & 5150 (a) \\
\hline Lower Calorific Value (kcal.kg-1) & $4480(b)$ & $4418(\mathrm{c})$ & 4896 (a) \\
\hline Elementary Chemical Analysis (\%) & $\begin{array}{c}\mathrm{C}=50.7 ; \mathrm{N}=0.2 ; \mathrm{H}=6.1 ; \\
\mathrm{O}=42.6 ; \mathrm{S}=0.2\end{array}$ & $\begin{array}{c}\mathrm{C}=49.2 ; \mathrm{N}=0.2 ; \mathrm{H}=5.9 \\
\mathrm{O}=44.3 ; \mathrm{S}=0.1\end{array}$ & $\begin{array}{c}\mathrm{C}=51.8 ; \mathrm{N}=0.1 ; \mathrm{H}=4.7 \\
\mathrm{O}=19.2 ; \mathrm{S}=2.5\end{array}$ \\
\hline \multicolumn{4}{|l|}{ Immediate Chemical Analysis: } \\
\hline Volatile Content (\%) & 87.61 & 87.00 & \\
\hline Ash Content (\%) & 0.23 (b) & 0.14 (b) & $19.86(a)$ \\
\hline Fixed Carbon Content (\%) & 12.15 & 12.86 & \\
\hline \multicolumn{4}{|l|}{ Structural chemical analysis: } \\
\hline Soluble extractives $(\%)$ & 583 & 5.16 & \\
\hline Soluble lignin $(\%)$ & 0.26 & 2.58 & \\
\hline Insoluble lignin (\%) & 31.14 & 33.24 & \\
\hline Lignina Total (\%) & 31.40 & 35.83 & \\
\hline
\end{tabular}

Revista Árvore 2019;43(2):e430201 
A

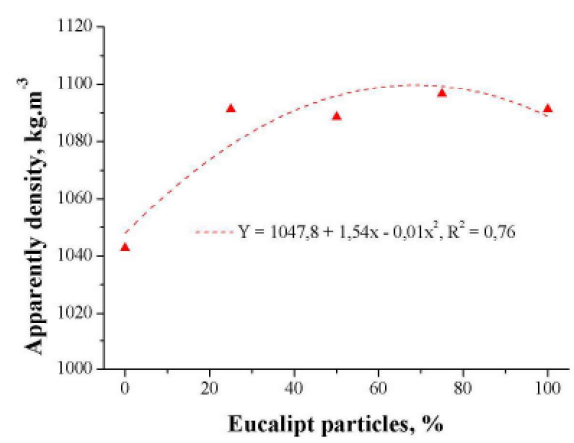

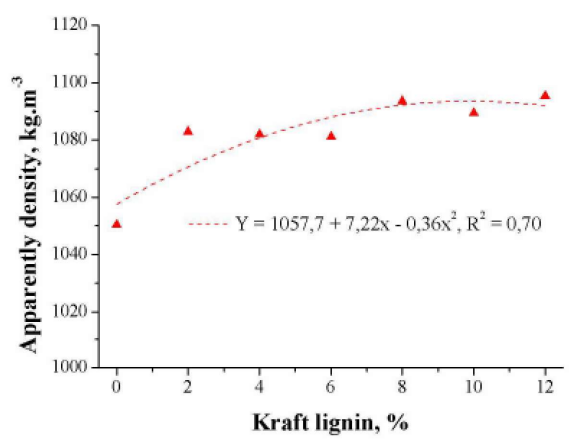

B

Figure 1 - Mean values observed and estimated by equations of apparent density the briquettes. A) according to the quantity of pine and eucalyptus particles (\%), B) according to addition of kraft lignin (\%).

Figura 1 - Valores médios observados e estimados de densidade aparente dos briquetes. A) em função da quantidade de partículas de pinus e eucalipto (\%), B) em função da adição de lignina kraft (\%).

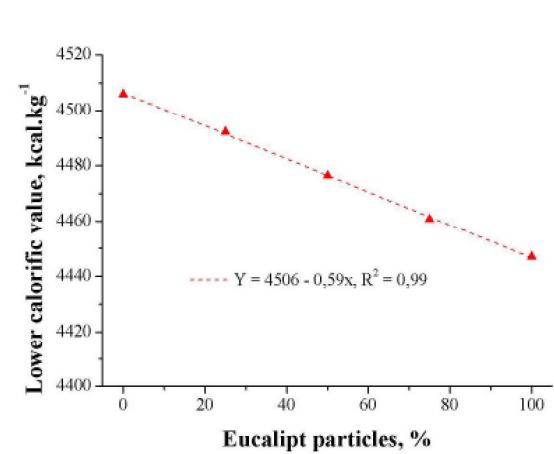

A

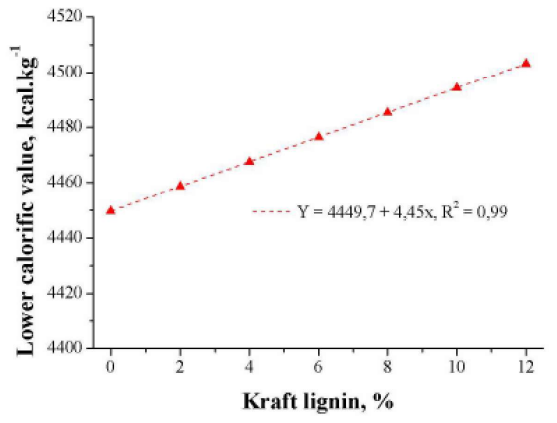

Figure 2 - Mean values observed and estimated by equations of lower calorific value the briquettes. A) according to the quantity of pine and eucalyptus particles (\%), B) according to kraft lignin addition (\%).

Figura 2 - Valores médios observados e estimados de poder calorífico inferior dos briquetes. A) em função da quantidade de partículas de pinus e eucalipto (\%), B) em função da adição de lignina kraft (\%).

In the bulk density of forest biomass, the eucalyptus particles were greater than that observed for the pine particles. These values explain the different compaction rates found in the briquettes, since they were made with the same amount of compaction mass and pressure.

\subsection{Briquettes properties}

The maximum apparent density was reached at a proportion of $75 \%$ eucalyptus particles $(1102$ $\left.\mathrm{kg} \cdot \mathrm{m}^{-3}\right)$. In relation to the proportion of kraft lignin in the briquette composition, the best result was obtained at $12 \%$. These increases were $3 \%$ and $4 \%$ in relation to the eucalyptus particles and to the addition of lignin, respectively, therefore being considered low. The explanation may be due to the different compaction rates obtained as a function of the same pressure used for all briquettes.

According to Iwakiri et al. (2008), the apparent density of the compacted biomass is greater the lower the density of the source material. However, briquettes made with a higher proportion of eucalyptus particles, which have a higher bulk density in comparison to pine, did not present lower apparent density values. This contradiction can be explained by the different compression ratio for the different briquettes produced, because they are produced with the same amount of mass, with different percentages of different bulk density (pine, eucalyptus and lignin) and compacted under the same pressure.

In a study conducted by Gouvêa (2012) on the production of briquettes from a mixture of kraft lignin 
A
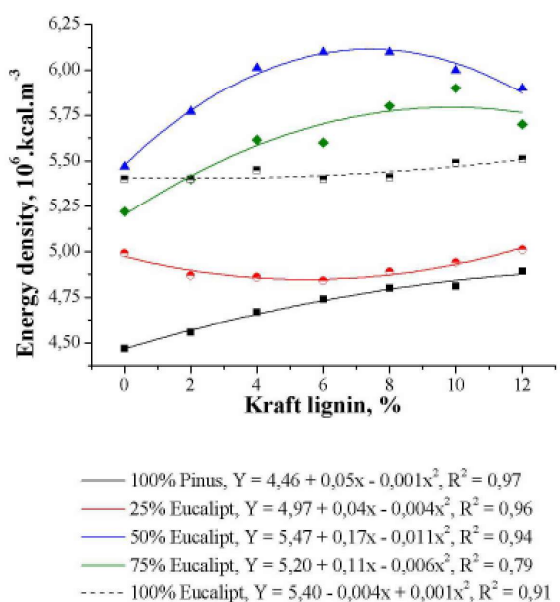

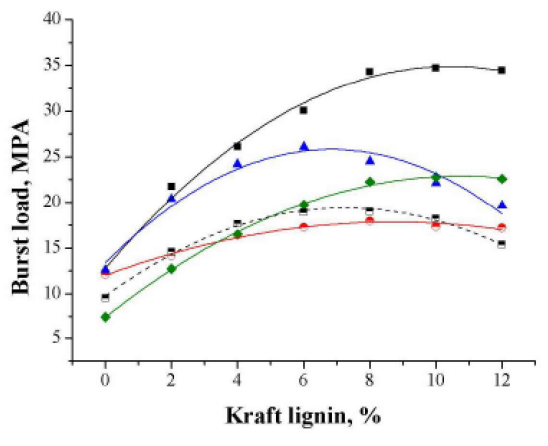

$100 \%$ Pinus, $Y=12,8+4,22 x-0,20 x^{2}, R^{2}=0,89$ $25 \%$ Eucalipt, $Y=12,0+1,33 \mathrm{X}-0,07 \mathrm{X}^{2}, \mathrm{R}^{2}=0,95$ $-50 \%$ Eucalipt, $Y=13,4+3,62 \mathrm{X}-0,26 \mathrm{X}^{2}, \mathrm{R}^{2}=0,91$ - $75 \%$ Eucalipt, $Y=7,44+2,86 \mathrm{x}-0,13 \mathrm{x}^{2}, \mathrm{R}^{2}=0,79$ -..- $100 \%$ Eucalipt, $Y=9,76+2,64 x+0,18 x^{2}, R^{2}=0,90$

Figure 3 - Mean values observed and estimated by equations of the briquettes produced with different pines and eucalyptus particle contents as a function of kraft lignin content. A) energy density and B) maximum burst load.

Figura 3 - Valores médios observados e estimados dos briquetes produzidos com diferentes proporçôes de particulas de pinus e eucalipto em função da adição de lignina kraft. (A) densidade energética. (B) carga máxima de ruptura.

and residues from the furniture industry pressed at different temperatures $\left(60^{\circ} \mathrm{C}, 75^{\circ} \mathrm{C}\right.$ and $\left.90{ }^{\circ} \mathrm{C}\right)$, there was an increase in the apparent density of the briquettes with the increase of lignin content, reaching a higher value when $20 \%$ of lignin was added at all compaction temperatures.

In this study, a direct relationship between lignin increase and apparent density in the briquettes was also observed, given that the amount of lignin added to the particle composition caused small changes in the volume of the briquettes, since the mass was the same for all the treatments.

It is observed in Figure $3 \mathrm{a}$ that the addition of eucalyptus particles in the briquettes resulted in an inverse proportional effect for the lower calorific value, given that the LCV of eucalyptus (4418 kcal. $\left.\mathrm{kg}^{-1}\right)$ is the lowest amongst the components, with pine being (4480 kcal. $\left.\mathrm{kg}^{-1}\right)$ and kraft lignin (4896 kcal. $\left.\mathrm{kg}^{-1}\right)$. Thus, increasing the proportion of eucalyptus content reduces the proportion of the other components, and consequently reduces the LCV of briquettes. In Figure $3 \mathrm{~b}$, the addition of kraft lignin had a direct proportional effect on the LCV of the briquettes, which was to be expected, given that its contribution to the calorific value is greater.

As for energy density, it is observed in Figure 3a that the amount of energy stored per unit volume in the briquettes had a greater influence on the composition of the particles than the addition of kraft lignin. The values for energy density indicated that the best results were seen in briquettes made with $50 \%$ of each biomass (pine and eucalyptus), followed by briquettes composed of 75 and $100 \%$ eucalyptus, respectively. These values are explained by the variation of apparent density in the briquettes in relation to the proportion of eucalyptus particles, which had a significantly positive relation, presenting a correlation coefficient of 0.49 .

Another point to be observed in energy density is the positive effect of the addition of kraft lignin. Note that there was an increase for most treatments, except in briquettes made with $25 \%$ eucalyptus. The most significant increases were 12,11 and $9 \%$ in relation to the control treatment ( $0 \%$ kraft lignin), with the addition of 6,8 and $12 \%$ kraft lignin in briquettes made with $50 \%$ and $75 \%$ eucalyptus, and $100 \%$ pine, respectively.

In addition to energy density, another property influenced by the composition of the particles and the addition of kraft lignin was the mechanical resistance of the briquettes. The results showed that with $25 \%$ eucalyptus particles there was a decrease in the mechanical resistance of briquettes. It is observed in Figure $3 \mathrm{~b}$ that the highest maximum bursting load reached for briquettes with $100 \%$ pine, this is because, with its being a less dense

Revista Árvore 2019;43(2):e430201 
wood than eucalyptus, there is a higher compaction rate due to the greater cohesion strength between the particles. Concerning the briquettes made with a mixture of pine and eucalyptus, the composition of $50 \%$ of eucalyptus was the one that presented better results.

Additionally, the addition of kraft lignin gave the briquettes greater strength, which was expected. Therefore, the compaction temperature $\left(120{ }^{\circ} \mathrm{C}\right)$ was higher than the glass transition temperature of the lignin (Kaliyan and Morey, 2010; Stelte et al., 2011). This added to the moisture content of the biomass, with a softening of the kraft lignin, which spread throughout the particles during compaction. After cooling, the lignin became rigid again, acting as a bonding agent between the particles, which gave greater mechanical resistance to the briquettes.

For briquettes made only with eucalyptus and with $50 \%$ eucalyptus, the addition of $7 \%$ lignin was the point of greatest mechanical resistance. For the other treatments, with up to $12 \%$ lignin added, the mechanical resistance increased as the proportion of lignin in the briquettes increased. In general, it can be inferred that, depending on the proportion of biomass in the briquettes, there is an optimum lignin content, which gives the briquette maximum resistance, and that a high content of this component can reduce its mechanical resistance. The mechanical resistance of briquettes is important for usual movement, to avoid crushing or breaking during transport or fall.

It was found after the production of the briquettes, as well as by Gouvêa (2012), that they presented a hydrophobic film on its external surface, which may promote a reduction of its hygroscopic equilibrium moisture. This factor is important, since a lower moisture content in the briquette gives it a greater useful calorific value.

\section{CONCLUSIONS}

The apparent density in the briquettes increased with the lignin content and, with the increase of up to $75 \%$ of eucalyptus particles in its composition. The lower calorific value of the briquettes was proportional to the increase of the lignin content, and to the increase of the percentage of pine particles.
The composition of the briquette particles had a greater influence on the increase in the energetic density in comparison to the addition of kraft lignin, being more notable in briquettes made with a greater proportion of eucalyptus.

The increase of the lignin content gave the briquettes a higher bursting load. However, for briquettes made with $100 \%$ eucalyptus and 50\% eucalyptus, the mechanical resistance presented a maximum value for the addition of $7 \%$ of lignin. For briquettes made with $100 \%$ pine, $25 \%$ eucalyptus and $75 \%$ eucalyptus, the maximum burst load was achieved by adding $11 \%$ lignin. In addition, briquettes made with only pine achieved a higher burst load.

In general, kraft lignin presented a good potential for use as a briquette additive leading to improved energy and mechanical properties. However, due to the variation of the values of its properties in relation to the proportion of lignin used, further research to test kraft lignin with a lower ash content is recommended.

\section{REFERENCES}

Associação Brasileira de Normas Técnicas - ABNT. NBR 8112: Análise química imediata do carvão vegetal. Rio de Janeiro: 1986.

Associação Brasileira de Normas Técnicas - ABNT. NBR 11941: Madeira, determinação da densidade básica. Rio de Janeiro: 2003.

Associação Brasileira de Normas Técnicas - ABNT. NBR ISO 11093-9 - Papel e cartão - Ensaio de tubetes - Determinação da resistência ao esmagamento. Rio de Janeiro: 2009.

Association Standard Test Method - ASTM D2015: Gross calorific value of coal and coke by the adiabatic bomb calorimeter. Philadelphia: 1982.

Berghel J, Frodeson S, Granstrom K, Renstrom R, Stahl M, Nordgren D, et al. The effects of kraft lignin additives on wood fuel pellet quality, energy use and shelf life. Fuel Processing Technology. 2013;112:64-9.

Glaser WG. Potential role of lignin in tomorrow's wood utilization technologies. Forest Products Journal. 1981;31(3):24-9.

Goldschmid O. Ultravioleta spectra. In: Sarkanem $\mathrm{K}$, Ludwing CH. Lignins: ocurrence, formation, 
structure and reactions. New York: J. Wiley; 1971. p.241-98.

Gomide JL, Demuner BJ. Determinação do teor de lignina na madeira: método Klason modificado. $\mathrm{O}$ Papel. 1986;47(1):36-8.

Gosselink RJA, Guran B, Abächerli A. Co-ordination network for lignina-standardisation, production and applications adapted to Market requirements (Eurolignin). Industrial Crops and Products. 2004;20:121-9.

Gouvêa AFG, Silva CM, Carneiro ACO, Freitas FP, Carvalho AMML, Gomide JL. Produção de briquetes a partir de resíduos de madeira e lignina do licor negro kraft: primeiros estudos [cd-rom]. In: Anais do $12^{\circ}$ Encontro Brasileiro em Madeira e Estrutura de Madeira -XII Ebramem. Lavras: 2010.

Gouvêa AFG. Produção de briquete a partir da adição de lignina kraft com resíduos da indústria moveleira [tese]. Viçosa, Minas Gerais: Universidade Federal de Viçosa; 2012.

Iwakiri S, Albuquerque CEC, Prata JG, Costa ACB. Utilizaçao de madeiras de Eucalyptusus grandis e Eucalyptusus dunni para produção de painéis de partículas orientadas - OSB. Ciência Florestal. 2008;18(2):265-70.

Kaliyan K, Morey RV. Factors affecting strength and durability of densified biomass products. Biomass \& Bioenergy. 2009;33(3):337-59.

Kaliyan N, Morey RV. Natural binders and solid bridge type binding mechanisms in briquettes and pellets made from corn stover and switchgrass. Bioresource Technology. 2010;101(3):1082-90.

Lora JH, Glasser WG. Recent application of lignina: A sustainable alternative to nonrenewble materials. Journal of Polymers and the Environment. 2002;10:39-48.

Regazzi A. Teste para identificar a identidade de modelos de regressão e igualdade de alguns parâmetros num modelo polinomial ortogonal. Revista Ceres.1993;40(228):176-95.

Regazzi A, Silva CHO. Teste para verificar a igualdade de parâmetros e a identidade de modelos de regressão não-linear. I. Dados no delineamento inteiramente casualizado. Revista Matemática Estatística. 2004;22(3):33-45.

Stelte W, Holm JK, Sanadi AR, Barsberg S, Ahrenfeldt J, Henriksen UB. A study of bonding and failure mechanisms in fuel pellets from different biomass resources. Biomass \& Bioenergy. 2011;35(2):910-8.

Stolarski MJ, Szczukowski S, Tworkowski J, Krzyżaniak M, Gulczyński P, Mleczek M. Comparison of quality and production cost of briquettes made from agricultural and forest origin biomass. Renewable Energy. 2013;57:20-6.

Technical Association of the Pulp and Paper Industry - TAPPI. TAPPI T264 cn-97: Preparation of wood for chemical analysis. Atlanta: Tappi Press; 1997.

Tomani P. The lignoboost process. Celulose Chemistry and Technology. 2010;44:53-8.

Valadares LB, Freitas FP, Gouvêa AFG, Silva CM, Carvalho AMML, Carneiro ACO, et al. Potencial da lignina do licor negro kraft para a produção de briquetes [cd-rom] In: Anais do $6^{\circ}$ Congresso Internacional de Bioenergia. Curitiba: 2011.

Vital BR. Métodos de determinação da densidade da madeira. Viçosa, MG: SIF; 1984. (Boletim técnico, 1). 